\title{
GOVERNANCE \& SHARIA ISSUES IN INVESTMENT ACCOUNT
}

YaseerTaufik Syamlan

1Ta zkia Islamic University College, Bogor

ya seersyamlan@tazkia.ac.id

\begin{abstract}
Corporate Governance and Sharia Governance has been the main key of the existence of Islamic finance industry. Recently there are some issues which related to governance which are sharia arbitrage, Investment account holder treatment and the need of professional ethic for Sharia Supervisory Board member. These three issues if in the future can be managed properly will take the industry forward. But, the practice of good corporate and sharia governance still based on the Islamic Finance discretion. Since the Islamic finance industry still growing, the carefulness in conducting all transaction with a spirit of good corporate and sharia governance will be benefit to the development of industry in the future.

Keywords:Corporate governance, sharia governance, sharia arbitrage, treatment of IAHs, professional ethics for SSB member.
\end{abstract}




\section{Introduction}

The fast growing Islamic industry last decade give a new perspective for the finance industry about how to behave ethically in the financial market. It is all about investing with responsibility and with high consent and understand the role, right, and power of each party. The holy book really emphasize on these thing. Allah via the holy book, has prohibit riba to empower justice in economy and giving maslahah to the ummah.

To give a strong implication for ummah and industry, Islamic finance needs a set of rule that direct all market players to gain just economy. Islamic finance requests a good governance system either in corporate level or national level. Well, the rule is different than in conventional system which used riba as a profit.

By nature, Islamic finance has its own uniqueness. It is based on the Islamic principles which is written in holy qur'an and narrated in the hadist. Some of the difference is on the deposit taken by the Islamic bank. Islamic bank use wadiah principle as saving account and mudaraba as investment account. Wadiah principle almost has same feature with the conventional saving account expect the hibah which given based on bank discretion. Meanwhile, the concept of mudaraba which use as investment account implies a special treatment for the depositor. It is the difference. Conventional banks just gave interest as return for depositor. But, in case of Islamic bank, the restricted investment account holder deserved more than return, they have to be informed with a set of continuous information about their investment (Syamlan 2018).

This research will emphasis on the issued on the corporate and sharia governance in Islamic finance. This paper contains 4 sections. First section is introduction, talk about the big picture of the issues. The second sections will touch in the general concept of corporate and sharia governance in brief. The third section will explain and elaborate deeply on the issue of treatment of investment account holder.

\section{Corporate and Sharia Govemance ata Glance}

Governance system is an integral feature of Islamic bank and finance. Being accountable, transparent and trustworthy is expected of Muslim as well as corporations run by Muslim or operating in line with shariah. Islamic financial institution (IFI) must give special attention to the implementation of good governance practice as it will enhance the accountability, transparency and trustworthiness of IFI. The principles and practices of good governance are in line with Islamic principle (IFSB 2006).

\section{Corporate Governance}

Corporate governance is a process to ensure that the business and management of corporate entities are carried out in the best possible manner to safe guard and promote the interest of all stakeholders (Ghayad 2008).

From the view point of corporate governance, IFI differs from his conventional counterpart. For example, in case of Islamic bank, they require more committee like 
governance committee according to IFSB guideline to at least secure the interest of investment account holder. While in conventional bank the engagement between the bank and customer just mere on giving sufficient and satisfying return. Islamic bank are required to do equity participation and profit and loss sharing for the basis of Islamic financing (Archer and Karim 2007).

In principle, both IFI and conventional financial institution share same principle of corporate governance. The principles of Good Corporate Governance (GCG) from conventional perspective are in line with the shariah principle. Some key principle of GCG are: (Van Greuning and Iqbal 2008)

- A well-articulated corporate strategy against which the overall success and the contribution of individuals can be measured;

- The assignment and enforcement of clear responsibilities, decision making authority, and accountabilities that are appropriate for the financial institution's profile;

- A strong financial risk management function (independent business lines), adequate internal control systems (including internal and external audit functions), and a functional process with the necessary checks and balances.

- Adequate corporate values, code of conduct, and other standards appropriate behavior and effective system for ensuring compliance including special monitoring of financial institution risk exposure where conflict of interest are expected to appear.

- Financial and managerial incentives of the board, management, and employees to act in an appropriate manner, including compensation, promotion, and penalties.

There are two types of corporate governance, which are statutory regulation and self regulation. Statutory regulation are provided for under relevant legislative provisions and are legally binding such as duties, responsibilities and powers of Sharia Supervisory Board (SSB) member which stipulated on BNM GP1-I. While self regulation means that matters concerning corporate governance are established via code of best practices that are recommended adopted by IFI like guidelines from IFSB.

Both types of governance when it comes to the implementation might have several implications depend on the approach used. Malaysian code on corporate governance explains these approaches, which are:

- Perspective based approach. Where the standard of corporate governance is set by specifying desirable practices coupled with a requirement to disclose compliance of them. For example, London stock exchange and Bursa Malaysia adopts standard best practices benchmark for all listed companies.

- Non-perspective based approach. This approach simply requires corporate governance practices in a company to be disclosed. The emphasis is on the disclosure of actual corporate governance practices. The thinking behind this approach each company may have different situation so that cannot implement the standard. This approach actually provide a just the principle 
not the standards. Each company has a room to use the principle according to the need and circumstances which company faced. The Australian Stock exchange has taken this approach and IFSB doing so.

- Hybrid approach. This is approach preferred by Hample committee. The committee considered there is need for broad principles and that all concern should then apply flexibly and with common sense based on companies circumstances (SCM 2000).

\section{Islam and Corporate Governance}

Strong corporate governance is important for the development of a sound Islamic finance industry. Again, corporate governance is not new in Islam. In general, Islamic concept of corporate governance emphasizes on three main areas, which are accountability, transparency, and trustworthiness.

Transparency, in the holy book, Al-Baqarah verse 282, states;

"O you believe! When you contract of debt fixed period, write down it. Let a scribe write it down in justice between you. You should not become weary to write your contract down, whether large or small, for its fixed term, that is more just with Allah, more solid as evidence and more convenient to prevent doubts among yourselves...Take witness whenever you enter into a commercial contract...."

This verse touches about the need of carefully record every transaction to avoid injustice and concealing any detail that might lead for future injustice.

In underlining trustworthiness, the Quran states in Al-Anfal verse 27

"O ye that believe! Betray not the trust of god and apostle, nor misappropriate knowingly things entrusted to you"

Islam also looks into the essence of responsibility, the concept of work, dedication to work and trusteeship. This gives Islamic corporate governance very comprehensive coverage.

Responsibility, like accountability, implies being responsible not only towards human being but also performing one's role in life. This role is given as an amanah (trust) from god. Should one neglect this responsibility, it is a form of khianat (betrayal) to god. The concept of work and dedication to work is a form of ibadah (worship) and amalShalih (virtuous act). In addition, khilafah (trusteeship) emphasizes that qualities of a good Islamic manager are also qualifies of a practicing Muslim.

Another commandment for Muslims is the concept of tawhid, which promotes the need to submit fully to God. It shows the unique and distinguishes relationship between man and Allah. This relationship also prevents man from behaving any manner that is harmful to other living things. By enforcing full submission to the creator and by insisting that the creators expects trustworthiness, transparency and responsibility in all dealings corporate governance is given a spiritual backing.

The elements of corporate governance which being basic elements of faith provide for IFI are:

- Aqidah: Concerns all form of faith and belief in Allah

- Syariah : Concerns practical actions taken by a muslim manifesting his faith and belief 
- Akhlaq : Covers all aspects of Muslim's behavior, attitude, and work ethics.

Corporate governance in IFI is thereof covered by shariah. It needs to be repeated here that Shariah in IFI has crucial role not only in governing their dealings and operations but also in monitoring and supervising the roles of all players within the financial system (Hassan, Shanmugam, and Perumal 2005).

\section{Investment Account Holder (IAH) Treatment}

\section{The Concept of Investment Account Holder}

An Islamic bank which is one of the types of Islamic Finance Institution is established to conduct their financial in accordance with Islamic rule and principles which in principle prohibit any kind of riba transaction. In conventional banking system, the fund mobilization is based on riba as a return that banks give to depositors. While in Islamic banking, riba is prohibited and as an alternative they use two main types of accounts to mobilize funds, namely: (a) investment account, which are usually based on profit-sharing and loss or based on mudarabah contract which funds are managed on behalf of the their holders; and (b) current accounts. Investment accounts are different with equity account with account holder have a right to withdraw their funds and also have limited duration. Current accounts are sight deposit which like debt claim on the bank which can withdrawn any time (Archer and Karim 2009).

There are additional parties which come from the investment which are investment account holder (IAH). The funds from IAH include both restricted and unrestricted are invested at the bank discretion normally in the same pool as that in which bank's own funds and those from current accounts are placed. But, for the restricted investment account holder the fund are managed separately and dissimilar from bank's own funds.

The relationship between IAHs as providers of funds and the banks as fund manager is most regulated by the form of mudharabah contract. One absolute requirement for mudharabah is the transfer control over investment decision, including all operating policies from IAHs to the bank as mudharib. IAHs have no right to intervene the investment and the policies which are being prerogative right of mudharib. However, unlike the shareholder which have right to oversight their funds IAHs have no such right like that. This is the unique feature of Islamic bank.

\section{Practice in Industry}

A survey by IFSB revealed that there are more IIFS operating only unrestricted investment account than there are IFI offer only restricted investment account or both types of investment account (restricted and unrestricted). The survey also indicated that none of IFI who offer restricted investment account would allow IAH to restrict his investment mandate in line with his/her individual appetite. They are not offered such a "tailor-made" fund when IAH decide to open restricted investment account. The bank in restricted investment account case, not accommodating the specific risk appetite of potential IAHs and at the end the issue 
of fairness and transparency of IFI in managing the investment accounts give something to be notice (IFSB 2006).

Given that there are two type of IAH which are restricted and unrestricted account holder, logically the restricted IAH have stronger influence to management due to some restrictions that they specify when opening a restricted account. In fact, that concept did not applied accordingly in the industry. Many banks just offered "off-the-shelf" mudharabah investment account. It is a form of restricted mudharabah but the restrictions are not coming from the IAHs risk preference. Otherwise it comes from the preference of the bank which at the beginning has stated the restrictions to the customer. Consequently, the restricted and unrestricted account provides very weak monitoring arrangement provided by the mudharabah contract (Archer and Karim 2007).

\section{Baboration on Corporate Govemance and Sharia govemance issue}

The unique feature of Islamic bank in terms of mobilizing funds adds more governance and sharia issue. As noted before, based on mudharaba contract, bank have new stakeholder which is Investment Account Holders (IAHs). The treatment of the IAHs will raise new issue whether should or not giving a right to oversight their investment in the bank. In this section, the elaboration will both touch governance and sharia issue.

\section{A. Sharia Issue}

Archer and Karim said that according sharia jurisprudence, Islamic bank do not guarantee the value of the investment accounts based on mudarabah (Archer and Karim 2007). The implications, IAH have no power like creditor who have a variety control rights which they obtain when firms default which include the right in those circumstances to interfere in the major decision of firm. The claim of IAH on the earnings or asset is similar with the claim of the shareholder on the bank earning or assets. Moreover, while the mudharabah contract is neither a debt nor a conventional equity instrument, neither is it type of conventional hybrid instrument comprising debt and equity characteristics.

In the unrestricted mudarabah, IAHs authorize the bank to invest funds at its discretion including commingling with the shareholder fund. In the restricted mudahrabah, IAH will specify the type of investment in which the fund should be invested.

Generally speaking, IAHs as rabbul mal has no right to involve day to day in terms of investment decision. It is because when they do it, the contract of mudharabah will be void. When first concluding the contract of mudharabah, all the money and the right to control of it suddenly transferred to mudarib.

Mudarib, has prerogative right to use the fund. He can re-invest it to other business and commingle with his own money to run the business. Otherwise, mudarib should be strictly follow the requirements of rabbul mal in restricted mudharabah and separate the funds with the shareholder funds particularly.

When the yield of investment is positive, the shares of profit are allocated 
between the parties to the contract, IAHs, and the bank according to the proportionate share. Bank also entitled to any profit earned from investing the funds provided by current accounts as well as a contractual mudarib share of profit allocated to the IAHs as its fee for managing their funds. Again, the bank profit is to both generated from shareholder and to other funds investment portfolio that do not participate in profit sharing. Hence the shareholders receive the entire profit from this source and IAHs cannot claim any profit share from them. Otherwise, if the earning of investment is negative, according the mudharabah contract, loss should be borne by IAHs and Shareholders based on their investments. Like the shareholders, the liability of IAHs is limited to amount of their investment and no more. In the case of negative return, in addition to the shareholders proportion of loss that is determined, bank in the capacity of mudarib receive no profit sharing fee on behalf of shareholders. However if the loss is because of misconduct or negligence of bank, then they should bare the loss.

\section{B. Governance Issue}

Investment Account Holder is a person who deposit his/her fund trough mudharaba contract with Islamic bank. Some principles of governance on IAHs are:

1. Accountability, the Islamic bank is accountable to the IAH in terms of how they use the IAH fund. Especially in restricted mudharaba whereby the depositor state some restriction on the investment and Islamic bank must strictly engage with the restriction.

2. Transparency. Islamic bank must be transparent and disclose the PER to the IAH. They are also must be transparent on the kind of investment policy. Must make report on the usage of IAH money and ensure it is based on economic reality, not on "window dressing" to make them happy.

3. Communication, Banks and the IAH must be on the intense communication on the management of the investment. They must be provided information by information on their investment. it does not mean that they are given a bulk of information. Banks must be given by timely information and just on the essential information like investment policy, usage of fund.

4. Duty Care and Diligence. In managing the IAH fund, the person who in charge to manage the money based on Duty care and diligence by carefully investigate the investment opportunities and risk so that they can give considerable rate of profit to the IAH. In terms of purchasing securities they have to disclose the material information to IAH like price, transaction party, the fee, agent fee earned, etc.

The IAHs interest as rabbulmal is to have good return with less risk. This interest is against the manager interest. As manager of fund, Islamic bank want to maximize the usage of funds to gain more profit. Usually Islamic bank tends to take more risk because of the nature of mudharaba contract which provide no guarantee to the rabbul mal. Furthermore, it doesn't mean that Islamic bank not liable to rabbul mal when something happens and relate on their investment. They are liable to rabbul mal 
when wrong doing of funds happened. Likewise IAHs raise governance problem especially in terms of fairness and transparency. As the account formed under mudaraba contract, it can raise the agency problem. The mudaraba contract requires full transfer of control as well as the funds from rabbul mal to mudarib. Because of the control transfer and the nature of agency problem, there will be a notion that the mudarib who manage the fund will behave not on the IAHs interest. The transparency issue comes when talking about the usage of fund especially in case of restricted mudharaba account. The big question marks exist in a matter of the compliance of bank to the some restrictions that IAHs stated when conducting the contract. Another transparency comes from the disclosure of the exact profit amount that bank generate from the IAHs Fund.

Archer and Karim revealed IAHs has such a lack governance right that law accords to shareholder. The do not have: (1) the benefit of a board of directors to monitor the management on their behalf, whose members they appoint and can dismiss; (2) the right to receive an annual report and to appoint external auditor to audit the company; (3) the right to take a part and vote in annual general meeting or other general assembly; and (4) the right to participate in appointing the sharia supervisory board of the bank (Archer and Karim 2007). IAHs may not interfere the management of their fund by banks because any interference will nullify the contract. It also implied that IAHs has no right of oversight over the management of their investment. It means that the only possible act which can express the dissatisfaction of the IAHs is by exercising their right to terminate their contractual relationship with bank by withdrawing their fund.

\section{Scholar's Opinion on IAH Right}

Archer and Karim state that Islamic bank has a fiduciary duty towards two category of equity holders which are shareholder and IAHs (Archer and Karim 2007). The fiduciary duties that the bank, which represent by the management, owes to IAHs are governed by the mudharabah contract. IAHs are equity holders and residual claimants, and the bank in the capacity as mudarib owes them a fiduciary duty which should rank them similar to the treatment of the shareholder. IAHs in this case seem to be party whose right might be compromised.

If the mudharabah contract used to mobilize funds in a collective investment scheme, the scheme manager would have a primacy to the interest of the holders of mudharabah certificates because they are the owners of the fund. It will raise a dilemma for Islamic bank because they will face a conflict of interest between two categories of equity holders; Shareholders which has right to appoint, evaluate, dismiss the management and IAHs as the holders of certificates. The implications, IAHs will be classified as second class of equity holders. Archer and Karim opined that such classifications is kind of anomaly since IAHs has same residual claimants status which should entitle them the rights of governance as attached in shareholders (Archer and Karim 2007). They are denied any governance mechanism that could safeguard their interest and to mitigate potential conflict of interest 
between IAHs and common shareholders on the other hands, and between IAHs and the bank's management as the agent both for IAHs and common shareholder on the other hand.

Archer at al suggests that IAHs may be able to safeguard their own interest by relying on shareholders monitoring to operate on their behalf. It called as "vicarious monitoring" (Archer and Karim 2007).

D. IFSB Guidelines on IAH Treatment as Well as the Solution

The vicarious monitoring which suggested by Archer et. al, is same with the guideline on the IAHs which made by the IFSB. IFSB has come with guiding principles on corporate governance for institutions which offer Islamic financial services. These guidelines encourage IFIs to establish a comprehensive governance policy framework which empower each organ of corporate governance for balancing the IFI accountabilities to various stakeholders.

The guideline comes with an interesting idea with an establishment a governance committee. If we compare its function with audit committee, governance committee monitors the performance of board and management from the stand point of the IAHs interest while audit committee monitors primarily from the standpoint of shareholders. This committee will oversee and monitor the implementation of the governance policy framework by working together with management, audit committee and the SSB.

The appointment of member of governance committee will be another important point to be explained. The member, it would be preferable for independent nonexecutive director which possess skills not only ability to read and understand financial statements but also able to coordinate and link the complementary roles and functions of the governance committee and audit committee. It will be necessary to put member of SSB for the purpose handling shariah-related governance issues if any. Another member, it will be a good addition to have a member which has expertise on legal to cultivate a good corporate governance structure.

The empowerment of governance committee is to ensure that IAHs right of monitor the performance of their investment and associated risks are exercised. The IAHs right to monitor their investment should not be misinterpreting as a right to intervene the managements. The only thing that governance committee should do and it is the need of IAHs is the disclosure of their policies and practices in respect oftheir investment account. The committee is also having a duty to monitor the practice of smoothing return to preserve the transparency in any investing activities done by management as well as ensuring the transparency of financial reporting of the investment accounts. The expectancy of IAHs should be appreciated by conducting a sound investment strategy. They duty is also extend to ensure that the matter of sharia compliancy is really applied.

\section{Conclusions and Findings}

Islam support the conduct if good corporate governance. The principle of governance says accountability, responsibility, transparency, confidentiality, and 
trustworthiness are in line with the Islamic principle which written in the holy book. In addition, given that similarity of principle between corporate governance and Islamic principle, the task of IFIs now is to exercise the principle of governance and having a healthy Islamic finance industry which purely comply with the sharia principle.

Recent practices of IFI in the industry found that there are some issues pertaining to the exercise of good corporate governance as well as sharia governance. Some issues need to be addressed such as the sharia arbitrage, treatment of IAHs, and the need of professional ethic for the member of SSB.

Sharia arbitrage will give danger implications to the Islamic finance industry. It will create such risk that the industry called it as sharia risk. The sharia risk happens when market players re-engineered the prohibited contract to be sharia compliance product. It will lead degradations of image for Islamic finance and give a confidence for those who said Islamic finance is just an "Islamization" of conventional finance practices which against the principle of sharia. El-Gamal encourages the market player to understand and apply the true spirit of Islamic law as an alternative of sharia arbitrage (El-Gamal 2006). This can be accomplished by understanding the economic functions served by classical by classical legal provisions and the general principles that prompted classical jurist to pursue those functions within their economic and legal environment. This will make the development of Islamic financial products effectively for all people, without need for Arabic names of classical nominate contracts and without hiding behind "Islamic" brand name.

Second issues are the treatment of IAHs. IAHs which usually govern under contract of mudaraba which implies transfer of control of resources which given by rabbul mal to mudarib. Under the contract of mudaraba the only right that IAHs has is just to terminate the contract when they feel unsatisfied with the performance of mudarib. The expectancy of IAHs in terms of risk is lower than the mudarib which love high risk to get more return using IAHs fund. To at least reduce the agency problem which comes under the mudaraba contract, the need of monitoring rights as advised by Archer and Karim should be given to IAHs. IFSB on their guidelines also support the argument of Archer and Karimby persuade IFI to shape governance committee which has main objective to securing the right of monitoring of the IAHs to push mudarib to exercise the due skill and diligence in managing the fund (Archer and Karim 2007).

Third issues are the existence of professional ethic for SSB members. Since there is no international body which governs all the qualified scholars who sit in the SSB, every single SSB has their own way to make professional ethic. The need of SSB professional ethic is urgently required to govern all the members behavior including the sanctions that they will faced when making a mistake. 


\section{References}

[1]Archer, Simon, and Rifaat Abdel Ahmed Abdel Karim. 2009. "Profit-Sharing Investment Accounts in Islamic Banks๑: Regulatory Problems and Possible Solutions." Journal of Banking Regulation $10 \quad$ (4): 300-306. https://doi.org/10.1057 亿̧br.2009.9.

[2]Archer, Simon, and Rifaat Ahmed Abdel Karim. 2007. "Specific Corporate Governance Issues in Islamic Banks." Islamic Finance: The Regulatory Challenge, John Wiley E Sons, Singapore, 310-41.

[3]El-Gamal, Mahmoud A. 2006. Islamic Finance: Law, Economics, and Practice. Cambridge University Press.

[4]Ghayad, Racha. 2008. "Corporate Governance and the Global Performance of Islamic Banks." Humanomics 24 (3): 207-16. https://doi.org/10.1108/08288660810899368.

[5]Greuning, Hennie Van, and Zamir Iqbal. 2008. "Risk Analysis for Islamic Banks, World Bank." Washington, DC, USA.

[6]Hassan, Vaseehar, Bala Shanmugam, and Vignesen Perumal. 2005. Corporate Governance An Islamic Paradigm. Serdang: Universiti Putra Malaysia Press.

[7]IFSB. 2006. “Guiding Principles on Corporate Governance for Institutions Offering Only Islamic Financial Services (Excluding Islamic Insurance (Takaful) Institutions and Islamic Mutual Funds)." Islamic Financial Service Board, no. December: 1-33.

[8]SCM, Securities Comission Malaysia. 2000. Malaysian Code on Corporate Governance. Securities Comission Malaysia.

[9]Syamlan, Yaser Taufik. 2018. “Does Dual Banking Differentiate The Investment Account Requirement?" Tazkia Islamic Finance and Business Review 11 (2): 80-106. https://doi.org/http://dx.doi.org/10.30993/tifbr.v11i1.132. 